\title{
Comparison of C-reactive Protein Levels in Patients With Lung Cancer and Chronic Obstructive Pulmonary Disease
}

\author{
Neringa Vaguliené ${ }^{1}$, Marius Žemaitis ${ }^{1}$, Skaidrius Miliauskas ${ }^{1}$, Daiva Urboniené $\dot{e}^{2}$, \\ Brigita Šitkauskiené $^{1}$, Raimundas Sakalauskas ${ }^{1}$ \\ ${ }^{1}$ Department of Pulmonology and Immunology, Medical Academy, Lithuanian University of Health Sciences, \\ ${ }^{2}$ Department of Laboratory Medicine, Medical Academy, Lithuanian University of Health Sciences, Lithuania
}

Key words: lung cancer; chronic obstructive pulmonary disease; C-reactive protein; chronic inflammation.

Summary. Objective. The aim of this study was to establish C-reactive protein (CRP) levels in serum of patients with lung cancer and chronic obstructive pulmonary disease (COPD) and evaluate the associations of CRP levels with clinicopathological characteristics.

Materials and Methods. In total, 140 persons were included in the study: 43 patients with lung cancer, 34 patients with lung cancer and COPD, 42 patients with COPD, and 21 healthy subjects. CRP analysis was performed with a serum protein analyzer using commercially available highsensitivity reagent kits.

Results. The C-reactive protein levels were significantly higher in the lung cancer patients with or without COPD compared with the COPD patients or the control group (20.42 \pm 1.95 and $22.49 \pm 2.31$ vs. $8.37 \pm 0.91$ and $2.49 \pm 0.47 \mathrm{mg} / \mathrm{L}$, respectively; $P<0.01$ ). The patients with advanced lung cancer had higher CRP levels compared with the patients suffering from early stage lung cancer (23.11 \pm 1.72 vs. $14.59 \pm 2.23 \mathrm{mg} / L, P<0.01)$. The CRP levels were significantly higher in the patients with early stage lung cancer compared with the COPD patients $(14.59 \pm 2.23 \mathrm{mg} / \mathrm{L}$ vs. $8.37 \pm 0.91 \mathrm{mg} / \mathrm{L}, P<0.05)$. No association was found between CRP and histology, lung function, and smoking status in the patients with lung cancer.

Conclusions. Chronic inflammation plays an important role in both diseases: lung cancer and COPD. However, it seems that inflammation is more pronounced in patients with lung cancer, as the CRP levels were significantly higher in these patients than other groups.

\section{Introduction}

Lung cancer is the major cause of cancer-related mortality in both men and women worldwide (1). There is growing body of evidence that chronic inflammation plays an important role in carcinogenesis. Oxidative damage related to inflammation can lead to carcinogenesis via inactivation of mutations in tumor suppressor genes or posttranslational modifications in proteins that are involved in DNA repair. It is known that proinflammatory cytokines such as interleukin 1, interleukin 2, tumor necrosis factor alpha, and tumor growth factor are able to stimulate the production of $\mathrm{C}$-reactive protein (CRP) and influence survival, growth, mutation, proliferation, differentiation, and migration of tumor cells (2). Several chronic inflammatory processes have been clearly associated with specific cancers, such as Crohn's disease with colorectal cancer, chronic pancreatitis with pancreatic cancer, and chronic obstructive pulmonary disease (COPD) with lung cancer (2). Lung inflammatory diseases

Correspondence to N. Vaguliené, Department of Pulmonology and Immunology, Medical Academy, Lithuanian University of Health Sciences, Eivenių 2, 50028 Kaunas, Lithuania E-mail: neringa.vaguliene@gmail.com such as COPD are characterized by leukocytic infiltration of the airways that is regulated by a variety of mediators such as cytokines, chemokines, and adhesion molecules (3). The epidemiological studies have shown that COPD is an important risk factor for lung cancer. Smokers with moderate or severe COPD have a 1.3- to 4.9-fold increased risk of lung cancer compared with smokers without COPD (4). Lung cancer is found in $40 \%-70 \%$ of patients with COPD, particularly in severe disease, and is a common cause of death in patients with COPD (5). The most likely explanation for the increased risk of lung cancer in COPD is the presence of chronic inflammation with an increased production of growth factors and angiogenic factors. Cessation of smoking in COPD patients reduces, but does not eliminate, the risk of lung cancer probably because inflammation persists even after smoking cessation (6). Smoking is a risk factor for the development of COPD as well as lung cancer. The inflammatory mediators and intracellular signaling pathways are potentially rel-

Adresas susirašinėti: N. Vagulienė, LSMU MA Pulmonologijos ir imunologijos klinika, Eivenių 2, 50028 Kaunas

El. paštas: neringa.vaguliene@gmail.com 
evant in the pathogenesis link between COPD and lung cancer.

CRP is an acute-phase protein, which is produced in the liver in response to elevated cytokine levels after an inflammatory stimulus (7). The short serum half-life and relatively robust and reliable response to inflammation make CRP an ideal candidate marker for inflammation. Recently, it has been shown that "acute-phase response" is also seen in a variety of diseases, such as cardiovascular disease, diabetes, systemic inflammatory diseases, some autoimmune disorders, and cancer (8-9). CRP levels have also been used to predict cancer risk, detect cancer recurrence, and determine prognosis (1013). The role of chronic inflammation in the pathogenesis of lung cancer and its relation to the processes in COPD are still not fully understood. The aim of this study was to evaluate the levels of CRP, which is the marker of inflammation in patients with lung cancer, compare them with those from patients with COPD, and consequently analyze the relations between the expression of CRP and clinicopathological characteristics of patients.

\section{Material and Methods}

Subjects. A total of 140 subjects were examined: 43 patients with lung cancer, 34 patients with lung cancer and stable moderate-to-severe COPD, 42 patients with stable moderate-to-severe COPD, and 21 healthy individuals at the Hospital of the Lithuanian University of Health Sciences Kauno Klinikos from April 2009 till December 2010. All the patients met a number of criteria. They had not used inhaled and systemic steroids at least 1 month before the study. None of the subjects showed signs of acute respiratory infection at least one month before the investigations. Subjects were excluded if they had a history of another malignancy or other diseases associated with systemic inflammation, such as rheumatoid arthritis, inflammatory bowel disease, or connective tissue disorders, as these diseases may influence serum CRP levels. Before the patients with lung cancer received anticancer therapy, their clinical stage, tumor type, and performance status determined according to the Eastern Cooperative Oncology Group (ECOG) (14) were recorded at the time of diagnosis. The stage was determined according to the TNM Classification of Malignant Tumours, the sixth edition (15). The patients with lung cancer were divided into two groups according to the stage: early lung cancer - patients with stage I-II cancer, and advanced lung cancer - patients with stage III-IV cancer. COPD was diagnosed according to the criteria of the Global Initiative for Chronic Obstructive Lung Disease (GOLD) (16). The COPD patients were clinically stable (no exacerba- tion during the previous 2 months) at the time of examination. All the COPD patients were screened for the deficiency of alpha-1 antitrypsin (AAT), and none of the patients had $\mathrm{Z}$ allele, which may cause genetically determined deficiency of AAT.

The study subjects were divided into 3 categories according to their smoking status: smokers, currently smoking persons with a smoking history of more than 10 pack-years; ex-smokers, individuals with a smoking history of more than 10 pack-years who had ceased smoking more than 2 years before the study; and never-smokers, individuals who have never smoked. To calculate pack-years of smoking, the total number of years of smoking was multiplied by the average number of cigarettes smoked per day and divided by 20 (years $\times$ cigarettes per day $/ 20$ ).

Body mass index (BMI) was calculated as weight in kilograms divided by the square of height in meters.

The Kaunas Regional Ethics Committee for Biomedical Research approved the study, and written informed consent was obtained from all participants.

Lung Function Testing. Lung function was measured by spirometry using a pneumotachometric spirometer "Custo VitM" (Custo Med, Munchen, Germany) with subjects in the sitting position, and the highest value of forced expiratory volume in 1 second $\left(\mathrm{FEV}_{1}\right)$ and forced vital capacity (FVC) from at least two technically satisfactory maneuvers differing by less than 5\% was recorded. Predicted values were obtained from Quanjer et al. (17). The subjects had to avoid the use of short-acting $\beta_{2}$-agonists at least 8 hours prior the test.

CRP Measurement. Peripheral venous blood samples were taken before receiving anticancer therapy. Serum CRP levels were measured using high-sensitivity CRP reagent kits (Dade Behring, USA) with a protein analyzer BNTM100 N. The lower detection limit was $0.15 \mathrm{mg} / \mathrm{L}$. Serum levels of $\leqslant 3.10 \mathrm{mg} / \mathrm{L}$ were defined as normal.

Statistical Data Analysis. Statistical data analysis was performed using the statistical SPSS for Windows 18.0 software package. The data are presented as mean \pm standard error of the mean and medians, with ranges. The categorical data were compared using the chi-square test. Differences among all the study groups (more than two groups) were evaluated using the Kruskal-Wallis test. Differences between two groups were evaluated using the Mann-Whitney $U$ test. The association between serum CRP level and clinicopathological characteristics was measured by the Spearman correlation coefficient. Statistical significance was set at $P<0.05$.

\section{Results}

The characteristics of the study population are described in Table 1. All the investigated groups 
Table 1. Clinical Characteristics of the Study Population

\begin{tabular}{|c|c|c|c|c|}
\hline Variable & $\begin{array}{c}\text { Patients With Lung } \\
\text { Cancer } \\
\mathrm{n}=43\end{array}$ & $\begin{array}{c}\text { Patients With Lung } \\
\text { Cancer and COPD } \\
n=34\end{array}$ & $\begin{array}{c}\text { Patients With } \\
\text { COPD } \\
\mathrm{n}=42 \\
\end{array}$ & $\begin{array}{c}\text { Healthy } \\
\text { Individuals } \\
\mathrm{n}=21\end{array}$ \\
\hline $\begin{array}{l}\text { Gender, n }(\%): \\
\text { Male } \\
\text { Female }\end{array}$ & $\begin{array}{r}36(83.7) \\
7(16.3)\end{array}$ & $\begin{array}{r}30(88.2) \\
4(11.8)\end{array}$ & $\begin{array}{r}37(88.1) \\
5(11.9)\end{array}$ & $\begin{array}{r}16(76.2) \\
5(23.8)\end{array}$ \\
\hline Age, mean \pm SEM, years & $62.2 \pm 1.4$ & $64.8 \pm 1.1$ & $65.3 \pm 1.2$ & $61.0 \pm 1.3$ \\
\hline BMI, mean \pm SEM, $\mathrm{kg} / \mathrm{m}^{2}$ & $27.6 \pm 0.4$ & $26.9 \pm 0.4$ & $28.9 \pm 0.7$ & $29.3 \pm 1.4$ \\
\hline $\begin{array}{c}\text { Smoking, n (\%): } \\
\text { Never-smokers } \\
\text { Ex-smokers } \\
\text { Smokers }\end{array}$ & $\begin{array}{r}6(13.9) \\
14(32.6) \\
23(53.5)\end{array}$ & $\begin{array}{r}4(11.8) \\
14(41.2) \\
16(47.0)\end{array}$ & $\begin{array}{r}8(19.0) \\
17(40.5) \\
17(40.5)\end{array}$ & $\begin{array}{l}6(28.6) \\
7(33.3) \\
8(38.1)\end{array}$ \\
\hline $\begin{array}{l}\text { Smoking pack-years, median (range): } \\
\text { Ex-smokers } \\
\text { Smokers }\end{array}$ & $\begin{array}{l}29.0(10-50) \\
43.0(15-70)\end{array}$ & $\begin{array}{c}37.5(15-63) \\
44.0(20-104)\end{array}$ & $\begin{array}{c}38.0(5-57) \\
33.0(15-94) \\
\end{array}$ & $\begin{array}{r}25.5(7-44) \\
28.0(13-56) \\
\end{array}$ \\
\hline $\mathrm{FEV}_{1}$, mean $\pm \mathrm{SEM}, \%$ pred. & $83.4 \pm 3.5^{*}$ & $51.3 \pm 2.5^{* *}$ & $55.6 \pm 2.3^{* *}$ & $109.1 \pm 4.3$ \\
\hline $\mathrm{FEV}_{1} / \mathrm{FVC}$ ratio, mean \pm SEM & $95.5 \pm 1.7^{*}$ & $68.0 \pm 2.1 * *$ & $76.6 \pm 2.2^{* *}$ & $107.3 \pm 2.0$ \\
\hline
\end{tabular}

$\mathrm{FEV}_{1}$, forced expiratory volume in one second; FVC, forced vital capacity; BMI, body mass index; COPD, chronic obstructive pulmonary disease.

${ }^{*} P<0.05$, compared with lung cancer/COPD, COPD, and control groups. ${ }^{*} P<0.05$, compared with lung cancer and control groups.

were matched for age, gender, BMI, smoking status, and smoking intensity. Elevated $(>3.10 \mathrm{mg} / \mathrm{L})$ serum CRP levels were observed more frequently in the lung cancer patients without $(95.3 \%, 41 / 43)$ or with $(94.1 \%, 32 / 34)$ COPD than in the patients with COPD $(80.5 \%, 33 / 41)$ or in the control group $(33.3 \%, 7 / 21)(P<0.05)$. The highest serum CRP levels were found in the groups of patients with lung cancer with or without COPD compared with the patients with COPD or control group (Fig. 1). The serum CRP levels in the patients with lung cancer did not significantly differ from those of the patients with lung cancer and COPD; therefore, these groups were merged into one for the further statistical analysis.

Serum CRP levels did not differ between the male and female patients with lung cancer $(19.68 \pm 2.12 \mathrm{mg} / \mathrm{L}$ vs. $24.21 \pm 5.13 \mathrm{mg} / \mathrm{L}, P>0.05)$; lung cancer and COPD $(22.67 \pm 2.49 \mathrm{mg} / \mathrm{L}$ vs. $26.41 \pm 12.74 \mathrm{mg} / \mathrm{L}, \quad P>0.05)$; or control group $(2.29 \pm 0.52 \mathrm{mg} / \mathrm{L}$ vs. $2.48 \pm 1.10 \mathrm{mg} / \mathrm{L}, P>0.05)$. In

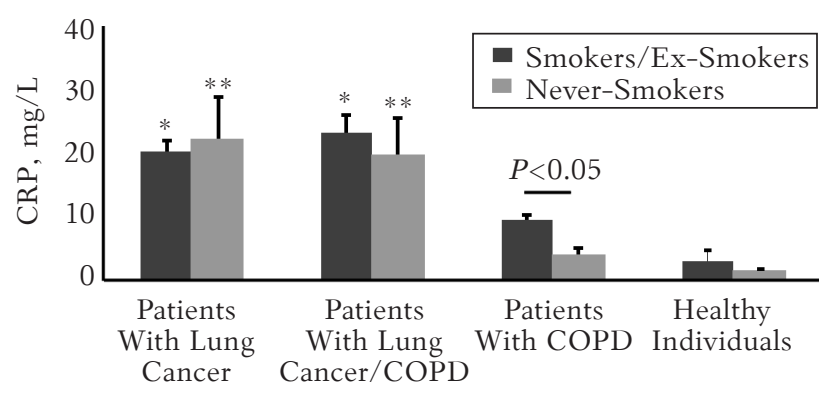

Fig. 1. Serum C-reactive protein (CRP) levels in smokers/ex-smokers and nonsmokers

Data are presented as mean \pm SEM.

${ }^{*} P<0.05$, compared with COPD smokers/ex-smokers,

$* * P<0.05$, compared with COPD never-smokers. the COPD group, serum CRP levels in the male patients were significantly higher than in the female patients $(8.94 \pm 0.96 \mathrm{mg} / \mathrm{L}$ vs. $3.18 \pm 0.66 \mathrm{mg} / \mathrm{L}$, $P<0.05)$. There was no significant correlation between serum CRP levels and age or BMI in the investigated groups (data not shown).

The clinical characteristics of the patients with lung cancer are described in Table 2. There were no significant differences in serum CRP levels among the major lung cancer histologic types: adenocarcinoma, squamous cell carcinoma, large cell carcinoma, non-small cell lung cancer not otherwise specified, small cell lung carcinoma $(18.59 \pm 4.67 \mathrm{mg} / \mathrm{L}$, $25.08 \pm 2.38 \mathrm{mg} / \mathrm{L}, 21.06 \pm 3.17 \mathrm{mg} / \mathrm{L}, 19.26 \pm 8.72$ $\mathrm{mg} / \mathrm{L}, \quad 18.72 \pm 3.31 \mathrm{mg} / \mathrm{L}$ ) as well as non-small cell lung cancer and small cell lung cancer groups $(22.31 \pm 1.76 \mathrm{mg} / \mathrm{L}$ vs. $18.72 \pm 3.31 \mathrm{mg} / \mathrm{L}, P>0.05)$. That is why these groups were also merged for the further analysis.

Serum CRP levels were significantly higher in the patients with advanced lung cancer than those with early lung cancer $(23.94 \pm 1.93 \mathrm{mg} / \mathrm{L}$ vs. $16.45 \pm 2.29$ $\mathrm{mg} / \mathrm{L}, P<0.05)$. The patients with early lung cancer had a significantly higher serum CRP level than the patients with COPD $(P<0.01)$ (Fig. 2).

Additionally, serum CRP levels were found to be higher in the lung cancer patients with poor performance status, i.e., with performance status $\geqslant 2$ compared with those with performance status $0-1$ $(P<0.05)$. In the lung cancer patients with good performance status, serum CRP levels were significantly higher than in the patients with COPD $(P<0.01)$ (Fig. 3).

According to subjects' smoking status, there were no significant differences in serum CRP levels among the smokers, ex-smokers, and never- 
Table 2. Characteristics of Patients With Lung Cancer at the Time of Diagnosis

\begin{tabular}{lc}
\hline \multicolumn{1}{c}{ Variable } & Patients, No. (\%) \\
\hline Lung cancer: & $62(80.5)$ \\
NSCLC & $15(19.5)$ \\
SCLC & $27(35.1)$ \\
\hline Histologic type: & $9(11.7)$ \\
Squamous cell carcinoma & $5(6.5)$ \\
Adenocarcinoma & $21(27.3)$ \\
Large cell carcinoma & $15(19.5)$ \\
NSCLC-NOS & \\
Small cell carcinoma & $13(16.9)$ \\
\hline Stage of disease: & $3(3.9)$ \\
Stage I & $25(32.5)$ \\
Stage II & $36(46.8)$ \\
Stage III & \\
Stage IV & $38(49.4)$ \\
\hline ECOG performance status: & $27(35.1)$ \\
0 & $6(7.8)$ \\
1 & $6(7.8)$ \\
2 &
\end{tabular}

NSCLC, non-small cell lung cancer; SCLC, small cell lung cancer; NSCLC-NOS, non-small cell lung cancer not otherwise specified; ECOG, Eastern Cooperative Oncology Group.

smokers in lung cancer groups without or with COPD $(P>0.05)$. Serum CRP levels were significantly higher in the smokers and ex-smokers with COPD compared with the never-smokers with COPD $(8.37 \pm 1.51 \mathrm{mg} / \mathrm{L}$ and $10.30 \pm 1.44 \mathrm{mg} / \mathrm{L}$ vs. $4.10 \pm 0.86 \mathrm{mg} / \mathrm{L}$, respectively; $P<0.05)$. Additionally, serum CRP levels were found to be higher in the never-smokers with lung cancer with or without COPD compared with the never-smokers with COPD $(23.43 \pm 5.91 \mathrm{mg} / \mathrm{L}$ and $19.95 \pm 5.72$ vs. $4.10 \pm 0.86 \mathrm{mg} / \mathrm{L}$, respectively; $P<0.01)$.

Serum CRP levels correlated with $\mathrm{FEV}_{1}(r=-0.609$, $P=0.001), \mathrm{FEV}_{1} / \mathrm{FVC}(r=-0.447, P=0.003)$, and smoking intensity $(r=0.584, P=0.001)$ in the patients with COPD. There was no significant correlation between serum CRP level and FEV $(r=-0.203$, $P=0.192), \mathrm{FEV}_{1} / \mathrm{FVC}(r=0.113, P=0.469)$, and smoking intensity $(r=-0.013, P=0.936)$ in the group with lung cancer; between serum CRP level and $\mathrm{FEV}_{1}(r=0.005, P=0.976), \mathrm{FEV}_{1} / \mathrm{FVC}(r=-0.329$, $P=0.057)$, and smoking intensity $(r=0.140$, $P=0.437)$ in the group with lung cancer and COPD; and between serum CRP level and $\mathrm{FEV}_{1}(r=-0.282$, $P=0.290), \mathrm{FEV}_{1} / \mathrm{FVC}(r=-0.283, P=0.287)$, and smoking intensity $(r=0.241, P=0.294)$ in the control group.

\section{Discussion}

This study was designed to evaluate serum CRP levels in patients with lung cancer and COPD. It was found that the patients with lung cancer had an elevated level of inflammatory marker CRP in comparison with healthy subjects. As in many previous studies, higher serum CRP levels were also found in COPD patients compared with healthy

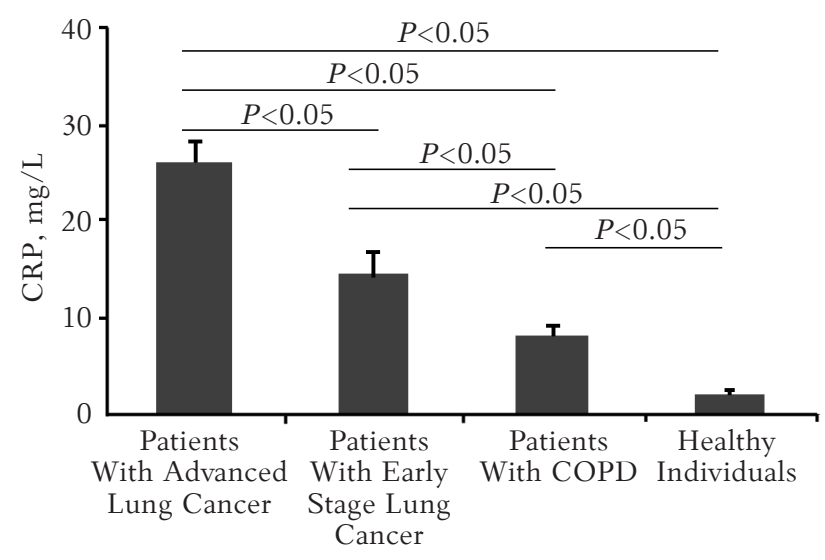

Fig. 2. Serum C-reactive protein (CRP) levels in patients with advanced and early stage lung cancer, patients with chronic obstructive pulmonary disease (COPD), and healthy individuals Data are presented as mean \pm SEM.

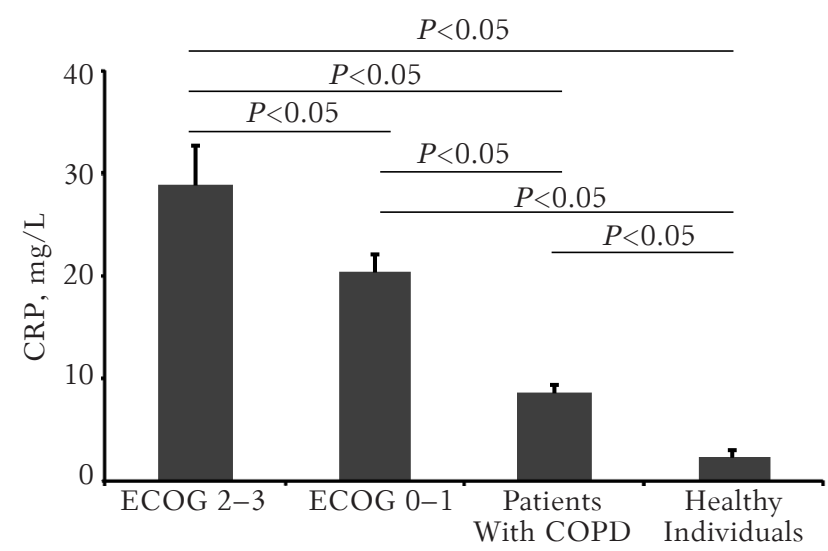

Fig 3. Serum C-reactive protein (CRP) levels in lung cancer patients with poor and good performance status according to the Eastern Cooperative Oncology Group (ECOG), patients with chronic obstructive pulmonary disease (COPD), and healthy individuals

Data are presented as mean \pm SEM.

subjects (18-19). Furthermore, in previous studies, CRP levels have been found to be highly elevated in patients with cancer compared with healthy control subjects or subjects with benign conditions $(8,20)$, and recent studies have reported increased serum CRP levels in patients with advanced non-small cell lung carcinoma (21). These findings suggest that chronic inflammation plays an important role in pathogenesis of lung cancer and COPD (2-3). However, there are still insufficient data linking systemic inflammation in both diseases. To our knowledge, it is the first study analyzing serum CRP levels in lung cancer patients with and without COPD and comparing CRP levels with these of COPD patients and healthy subjects. This study demonstrated that serum CRP levels were higher in both lung cancer groups (lung cancer, lung cancer and COPD) than in the patients with COPD, but there were no differences between the lung cancer patients with 
and without COPD. These data show that systemic chronic inflammation is probably more pronounced in lung cancer patients, but there is no additive effect in these two diseases consistent with those reported by other authors (22).

COPD is a disorder characterized by an abnormal local and systemic inflammatory response and is strongly associated with lung cancer $(3-4,23)$. Patients with lung cancer and COPD have an ongoing systemic inflammation, which can be assessed by measuring serum CRP. Several previous studies have suggested that increased serum CRP levels may predispose to the development of cancer (20, $24)$. It has been suggested that low-grade chronic inflammation may play a role in the pathogenesis of certain carcinomas. Elevated CRP concentrations are commonly observed in benign diseases (25), although there is also evidence that inflammatory lung diseases predispose individuals to lung cancer (26).

In our study, the patients with lung cancer and COPD did not differ in terms of age, gender, smoking status, or number of pack-years. Degree of airway obstruction did not differ between the lung cancer patients with COPD and COPD patients. BMI was also taken into account as it could increase CRP level. The systemic inflammation is associated with the development of cancer cachexia in patients with lung cancer (27). On the other hand, increased circulating levels of acute-phase proteins have been found to be associated with obesity (28). In this study, the average BMI did not differ in the patients with lung cancer and COPD. In this regard, it might be stated that the groups were well matched. However, no relationship between CRP and BMI was found in this study.

Lung cancer is classified to several histologic types, including small cell lung carcinoma and nonsmall cell carcinoma; the most common types of the latter are squamous cell carcinoma, adenocarcinoma, and large cell carcinoma. Treatment and prognosis depend on the histologic type of lung cancer. A recent study has shown that a higher CRP level was associated with squamous cell carcinoma (29). No significant differences in serum CRP levels or frequency of elevated CRP ( $>3.10 \mathrm{mg} / \mathrm{L})$ were found in our study among the major histologic types of lung cancer. Therefore, the hypothesis is raised that chronic inflammation is an early and universal process generating other alterations (including genetic) leading to lung cancer. It is necessary to address a few limitations to our study: the lung cancer analyses were based on a small number of lung cancer cases with different histologic types, which highlights the need for further larger prospective studies.

We also analyzed CRP levels in the patients with different stages of lung cancer (early vs. advanced). The patients with advanced lung cancer had higher serum CRP levels than the patients with early stage lung cancer; the difference was statistically significant and consistent with that reported in other studies $(21,29)$ accounting for additional evidence of the importance of chronic inflammation in lung cancer progression. In order to evaluate the impact of primary lung cancer on chronic inflammation itself, serum CRP levels in the patients with early lung cancer without loco-regional spread or distant metastasis and COPD were compared. Our findings of significantly higher serum CRP levels in the patients with early lung cancer than in the patients with COPD further support our hypothesis that chronic inflammation can be more pronounced in the patients with lung cancer. Higher CRP levels were found in the lung cancer patients with poor performance status. Previous findings that systemic inflammatory response was associated with a reduction in performance status in the patients with lung cancer were also reinforced. This systemic inflammatory response is associated with a poor prognosis in both operable and advanced inoperable carcinoma (27).

Deregulated inflammation is complicit in the pathogenesis of COPD and lung cancer, but the overlap of signaling events is not fully understood yet. Cigarette smoking is established as the leading risk factor for lung cancer and COPD (5). There is a growing body of evidence that tobacco smoke exposure promotes widespread inflammatory and $\mathrm{mu}-$ tagenic effects in the lungs that promote a procancer immune response (26). Recent studies have shown that CRP alterations and smoking status are independent prognostic factors for survival in patients with advanced non-small cell lung cancer $(30,31)$. However, the data on the influence of smoking itself on systemic inflammation in lung cancer patients with or without COPD are scarce. No difference in the mean CRP levels was observed between smokers, ex-smokers, and never-smokers with lung cancer with or without COPD. Although based on small numbers of studied subjects, our results suggest that inflammation due to other causes may be a relevant mechanism for lung carcinogenesis in never-smokers, too. Similarly, there was no difference between the patients with COPD who were current smokers and those who were ex-smokers (19). In contrast, never-smokers with COPD had significantly lower CRP levels than COPD smokers and ex-smokers. These findings may indicate the absence of an inflammatory response in smokers or persistent systemic inflammation in COPD patients even after smoking cessation, which is consistent with previous studies $(18-19,25)$. Our results showed that serum CRP levels in the nonsmoking patients with lung cancer with or without COPD were higher than in the nonsmoking patients with COPD and nonsmoking healthy subjects. These findings sup- 
port the hypothesis that tumor can probably release inflammatory mediators and initiate chronic inflammation succession in nonsmoking patients with lung cancer. The study showed that smoking history (pack-years) positively correlated with serum CRP levels in the patients with COPD, but in the patients with lung cancer (with or without COPD), no correlation was observed. Such a relation once again supports the role of cigarette smoking in inflammatory response in patients with COPD (18-19). Smoking may be the initial determinant factor for chronic inflammation and can create an environment leading to cancerogenesis.

\section{Conclusions}

The present study demonstrated that serum Creactive protein levels were significantly increased in the patients with lung cancer compared with the patients with chronic obstructive pulmonary disease and healthy subjects. Patients with lung cancer often have chronic obstructive pulmonary disease, which suggests that there are commonalities in the pathogenesis of these diseases. Chronic inflammation plays an important role in both diseases - lung cancer and chronic obstructive pulmonary disease - but it seems that it is more pronounced in lung cancer patients. Finally, more detailed understanding of the role of chronic inflammation in the pathogenesis of lung cancer and chronic obstructive pulmonary disease may have an important clinical diagnostic and prognostic implication.

\section{Statement of Conflict of Interest}

The authors state no conflict of interest.

\title{
C reaktyviojo baltymo kiekis sergant plaučių vèžiu ir lètine obstrukcine plaučių liga
}

\author{
Neringa Vaguliené $\dot{e}^{1}$, Marius Žemaitis ${ }^{1}$, Skaidrius Miliauskas ${ }^{1}$, Daiva Urboniené ${ }^{2}$, \\ Brigita Šitkauskiené ${ }^{1}$, Raimundas Sakalauskas ${ }^{1}$ \\ ${ }^{1}$ Lietuvos sveikatos moksly universiteto Medicinos akademijos Pulmonologijos ir imunologijos klinika, \\ ${ }^{2}$ Lietuvos sveikatos moksly universiteto Medicinos akademijos Laboratorinés medicinos klinika
}

Raktažodžiai: plaučiu vèžys, lètinė obstrukcinė plaučių liga, C reaktyvusis baltymas, lètinis neinfekcinis uždegimas.

Santrauka. Tyrimo tikslas. Nustatyti C reaktyviojo baltymo kiekị kraujo serume pacientams, sergantiems plaučiu vèžiu, plaučiu véžiu ir lètine obstrukcine plaučiu liga, lètine obstrukcine plaučiu liga bei nustatyti $\mathrm{C}$ reaktyviojo baltymo sąsajas su klinikinėmis ligų charakteristikomis.

Metodika. Tyrime dalyvavo 140 tiriamųiu: 43 sergantieji plaučių véžiu, 34 sergantieji plaučiu vèžiu ir lètine obstrukcine plaučiu liga, 42 sergantieji lètine obstrukcine plaučių liga ir 21 sveikas asmuo. Itvertintas visų tiriamųjų C reaktyviojo baltymo kiekis kraujo serume.

Rezultatai. Sergančiųjų plaučių véžiu bei plaučių vèžiu ir lètine obstrukcine plaučių liga kraujo serume nustatytas didesnis $C$ reaktyviojo baltymo kiekis nei sergančiųju lètine obstrukcine plaučių liga ir

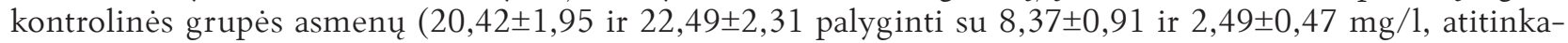
mai, $\mathrm{p}<0,01)$. Sergančiųjų lokaliai ir sistemiškai išplitusiu plaučių vèžiu kraujo serume nustatytas didesnis C reaktyviojo baltymo kiekis serume nei sergančiųjų neišplitusiu plaučiu vėžiu $(23,11 \pm 1,72$ palyginti su $14,59 \pm 2,23 \mathrm{mg} / 1$, atitinkamai, $\mathrm{p}<0,01)$. Sergančiųjų neišplitusiu plaučių věžiu kraujo serume nustatytas didesnis $C$ reaktyviojo baltymo kiekis nei sergančiųjų lètine obstrukcine plaučių liga $(14,59 \pm 3,36 \mathrm{mg} / 1$ palyginti su 8,37 $\pm 0,91$, atitinkamai, $\mathrm{p}<0,05)$.

Išvados. Šio tyrimo duomenys rodo, kad galimai sergantiesiems plaučiu vėžiu lètinis neinfekcinis uždegimas yra labiau išreikštas nei sergantiesiems lètine obstrukcine plaučių liga.

\section{References}

1. Jemal A, Siegel R, Ward E, Hao Y, Xu J, Thun MJ. Cancer statistics, 2009. CA Cancer J Clin 2009;59(4):225-49.

2. Coussens LM, Werb Z. Inflammation and cancer. Nature 2002;420:860-7.

3. Walter RE, Wilk JB, Larson MG, Vasan RS, Keaney JK, Lipinska I, et al. Systemic inflammation and COPD. The Framingham Heart Study. Chest 2008;133:19-25.

4. Skillurd DM, Offord KP, Miller RD. Higher risk of lung cancer in chronic obstructive pulmonary disease. A prospective, matched, controlled study. Ann Intern Med 1986;105:503-7.
5. Young RP, Hopkins RJ, Christmas T, Black PN, Metcalf P, Gamble GD. COPD prevalence is increased in lung cancer, independent of age, sex and smoking history. Eur Respir J 2009;34:380-6.

6. Babušytė A, Stravinskaitė K, Jeroch J, Lotvall J, Sakalauskas R, Šitkauskienè B. Patterns of airway inflammation and MMP-12 expression in smokers and ex-smokers with COPD. Respir Res 2007;8:81.

7. Pepys MB, Hirschfield GM. C-reactive protein: a critical update. J Clin Invest 2003;111:1805-12.

8. Bolayirly M, Turna H, Orhanoglu T, Ozaras R, Ilhan M, 
Ozguroglu M. C-reactive protein as an acute phase protein in cancer patients. Med Oncol 2007;24:338-44.

9. Sabatine MS, Morrow DA, Jablonski KA, Rice MM, Warnica JW, Domanski MJ, et al. Prognostic significance of the Centers for Disease Control/American Heart Association high-sensitivity C-reactive protein cut points for cardiovascular and other outcomes in patients with stable coronary artery disease. Circulation 2007;115:1528-36.

10. Mahmoud FA, Rivera NI. The role of C-reactive protein as a prognostic indicator in advanced cancer. Curr Oncol Rep 2002;4:250-5.

11. Wilop S, Crysandt M, Bendel M, Mahnken AH, Osieka R, Jost E. Correlation of C-reactive protein with survival and radiographic response to first-line platinum-based chemotherapy in advanced non-small cell lung cancer. Onkologie 2008;31:665-70.

12. Chiu HM, Lin JT, Chen TH, Lee YC, Chiu YH, Liang JT, et al. Elevation of C-reactive protein level is associated with synchronous and advanced colorectal neoplasms in men. Am J Gastroenterol 2008;103:2317-25.

13. McSorley MA, Alberg AJ, Allen DS, Allen NE, Brinton LA, Dorgan JF, et al. C-reactive protein concentrations and subsequent ovarian cancer risk. Obstet Gynecol 2007;109:933-41.

14. Oken MM, Creech RH, Tormey DC, Horton J, Davis TE, McFadden ET, et al. Toxicity and response criteria of the Eastern Cooperative Oncology Group. Am J Clin Oncol 1982;5:649-55.

15. Sobin L, Wittekind CH. TNM Classification of Malignant Tumours. 6th ed. New York: Wiley-Liss; 2002. p. 99-103.

16. Rabe KF, Hurd S, Anzueto A, Barnes PJ, Buist SA, Calverley P, et al. Global Initiative for Chronic Obstructive Lung Disease: Global strategy for the diagnosis, management, and prevention of chronic obstructive pulmonary disease: GOLD executive summary. Am J Respir Crit Care Med 2007;176:532-55.

17. Quanjer PH, Tammeling GJ, Cotes JE, Pedersen OF, Peslin $\mathrm{R}$, Yernault JC. Lung volumes and forced ventilatory flows. Report working party standardization of lung function tests, European Community for Steel and Coal. Official Statement of the European Respiratory Society. Eur Respir I Suppl 1993;16:5-40.

18. Pinto-Plata V, Mullerova H, Toso JF, Feudjo-Tepie M, Soriano JB Vessey R, et al. C-reactive protein in patients with COPD, control smokers and non-smokers. Thorax 2006;61:23-28.

19. Urbonienė D, Sakalauskas R, Šitkauskienė B. C-reactive protein levels in patients with chronic obstructive pulmonary disease and asthma. Medicina (Kaunas) 2008;44:833-40.

20. Chung HW, Kim JW, Lee JH, Song SY, Chung JB, Kwon

Received 18 July 2011, accepted 31 August 2011 Straipsnis gautas 201107 18, priimtas 20110831
$\mathrm{OH}$, et al. Comparison of the validity of three biomarkers for gastric cancer screening: carcinoembryonic antigen, pepsinogens, and high sensitive C-reactive protein. J Clin Gastroenterol 2009;43:19-26.

21. Lee JG, Cho BC, Bae MK, Lee CY, Park IK, Kim JD, et al. Preoperative C-reactive protein levels are associated with tumor size and lymphovascular invasion in resected nonsmall cell lung cancer. Lung Cancer 2009;63:106-10.

22. Mroczko B, Groblewska M, Gryko M, Kedra B, Szmitkowski M. Diagnostic usefulness of serum interleukin 6 (IL-6) and C-reactive protein (CRP) in the differentiation between pancreatic cancer and chronic pancreatitis. J Clin Lab Anal 2010;24:256-61.

23. Koshiol J, Rotunno M, Consonni D, Pesatori AC, de Matteis S, Goldstein AM, et al. Chronic obstructive pulmonary disease and altered risk of lung cancer in a population based case-control study. PLoS One 2009;4(10):e7380.

24. Heikkila K, Ebrahim S, Lawlor DA. A systemic review of the association between circulating concentrations of $\mathrm{C}$ reactive protein and cancer. J Epidemiol Community Health 2007;61:824-33.

25. De Torres JP, Pinto-Plata V, Casanova C, Mullerova H, Cordoba-Lanus E, Muros de Fuentes, et al. C-reactive protein levels and survival in patients with moderate to very severe COPD. Chest 2008;133:1336-43.

26. Sin DD, Man SFP, McWilliams A, Lam S. Progression of airways dysplasia and C-reactive protein in smokers at high risk of lung cancer. Am J Respir Crit Care Med 2006;173: 535-9.

27. Scott HR, McMillan DC, Forrest LM, Brown DJF, McArdle CS, Milroy R. The systemic inflammatory response, weight loss, performance status and survival in patients with inoperable non-small cell lung cancer. Br J Cancer 2002;87: 264-7.

28. Santos AC, Lopes C, Guimaraes JT, Barros H. Central obesity as a major determinant of increased high-sensitivity C-reactive protein in metabolic syndrome. Int J Obes 2005;29:1452-6.

29. Jones JM, McGonigle NC, McAnespie M, Cran GW, Graham AN. Plasma fibrinogen and serum C-reactive protein are associated with non-small cell lung cancer. Lung Cancer 2006;53:97-101.

30. Koch A, Fohlin H, Sörenson S. Prognostic significance of C-reactive protein and smoking in patients with advanced non-small cell lung cancer treated with first-line palliative chemotherapy. J Thorac Oncol 2009;4:326-32.

31. Hara M, Yonei A, Ayabe T, Tomita M, Nakamura K, Onitsuka T. Postoperative serum C-reactive protein levels in non-small cell lung cancer patients. Ann Thorac Cardiovasc Surg 2010;16:85-90. 